\title{
Accounting
}

\section{Investments in subsidiaries, joint ventures, affiliates and firm growth: Evidence from Vietnam}

\author{
Hoang N. Pham ${ }^{a^{*}}$ and Baliira Kalyebarab
}

${ }^{a}$ Victoria University, Melbourne, Australia

${ }^{b}$ American University of Ras Al Khaimah, United Arab Emirates

\section{H R O N I C L E}

Article history:

Received March 72020

Received in revised format March 102020

Accepted May 82020

Available online

May 82020

Keywords:

Affiliate investment

Firm growth

Controlling ownership

Corporate diversification

Vietnam

\section{A B S T R A C T}

This paper investigates the effect of investments in subsidiaries, joint ventures and affiliates (affiliate investment) on firm growth. Using both static and dynamic panel data models with a sample dataset of 2,056 firm-year observations on Vietnam's stock market from 2008-2015, the study finds that increasing affiliate investment in prior periods had a significantly positive impact on asset growth and net income growth (but not sales growth) of the firms in subsequent periods. In addition, the study finds new empirical evidence that private-controlled firms are more efficient than governmentcontrolled firms in terms of affiliate investment. It is also found that profitability, government ownership and foreign ownership are significant dynamics for firm growth. This research sheds light on the role of affiliate investment as a corporate diversification strategy to boost firm growth, including growth rates of multinational corporations. It also provides important implications about the determinants of different dimensions of firm growth in the context of an Asian emerging economy.

\section{Introduction}

The relationship between investment and firm growth provides important implications for the theory of the firm and the study of the determinants of firm growth. Investment as a dynamic of firm growth (or firm performance) has been studied from various perspectives, such as foreign direct investment (Chen \& Ku, 2000; Dimelis, 2005; Konings, 1997; Penrose, 1956), R\&D investment (Capasso, Treibich, \& Verspagen, 2015; Coad \& Rao, 2010; Coad, Segarra, \& Teruel, 2016), or investment in information technology (Weill, 1992). Nevertheless, further research into the association between investment and other aspects of firm growth is strongly encouraged because investment is a lumpy process (Coad, 2009).

'Investment in subsidiaries, joint ventures and affiliates' (hereinafter referred to as affiliate investment) is generally recognized as a component of non-current assets in the balance sheet of a firm. This treatment is based on the equity method in accounting (Scott, 2015). According to International Financial Reporting Standards (IFRS) and International Accounting Standards (IAS), a subsidiary is defined as 'an entity that is controlled by another entity' (IFRS 10). A joint venture is defined as 'a joint arrangement whereby the parties that have joint control of the arrangement have rights to the net assets of the arrangement', and 'an associate is an entity over which the investor has significant influence' (IAS 28). In Vietnam, affiliate investment is presented as a component of non-current assets and under the term 'long-term financial investment'. This entry covers all forms of longterm financial investment into subsidiaries, joint ventures and affiliates. Affiliate investment is indeed a form of financial resources invested externally by the firm. Such type of investment can be referred to as the expansion of the firm into related

* Corresponding author.

E-mail address: phamnguyenhoang@gmail.com (H. N. Pham) 
or unrelated industries to pursue growth and profit opportunities; whereby the firm's financial, physical and intangible resources are leveraged (Kim \& Rasheed, 2014). Investments in joint ventures and other forms of business collaborations are also classified as growth strategies of the firm (Copeland, Weston, \& Shastri, 2005). Hence, affiliate investment may play an important role in determining the growth rates of the firms across various dimensions such as assets, sales or net profit growth.

In the literature, however, little empirical evidence has been found on the relationship between affiliate investment and firm growth, where affiliate investment comprehensively covers all forms of long-term financial investment into subsidiaries, joint ventures and affiliates. There is a trend that prior scholars examine the impact of an individual form of affiliate investment on firm growth; for example, fixed asset investment (Cleary, 1999), investment in corporate venture capital (Cumming, Grilli, \& Murtinu, 2017; Dushnitsky \& Lenox, 2006; Engel \& Keilbach, 2007), and investment in working capital (Aktas, Croci, \& Petmezas, 2015), investment in equity ownership (Daily \& Thompson, 1994; Konings, 1997; Yang \& Meyer, 2018).

In the Vietnamese context, affiliate investment was extensively adopted by privatized state-owned enterprises (SOEs) during the period from 2008-2015 as a diversification strategy for fast firm growth to become large conglomerates (tap doan). It appears that this common practice was inspired by the Japanese (zaibatsu) or Korean (chaebol) models of industrial and financial business conglomerates. However, this strategy collapsed in the end after a range of corporate profit losses and corporate governance scandals. This is evidenced by the enactment of a series of regulations and policies by the Vietnamese government preventing the SOEs from making affiliate investments into non-core business lines. ${ }^{1}$

Therefore, this paper aims to investigate the relationship between affiliate investment and firm growth from an empirical perspective by using a panel dataset of 2,056 firm-year observations on Vietnam's stock market (257 firms from 2008-2015). This data sample is unique because it covers a specific period of time when large Vietnamese firms went bust as a consequence of excessive investments in affiliates and joint ventures. In addition, right now agendas for the SOEs are currently in effect. Hence, the Vietnamese context of study also provides an excellent practical experience to explore the impact of affiliate investment on the growth of government-controlled firms in comparison with that of private-controlled firms. This study seeks to answer two research questions: 1) Are affiliate investments negative or positive for firm growth?, and 2) Do affiliate investments contribute to the growth of private-controlled firms as much as to government-controlled firms?

Employing the fixed-effects (FE) estimations and system GMM estimations for dynamic panel data models, the study finds that intensifying affiliate investment in prior periods does contribute to asset growth and net profit growth of the subsequent periods. Interestingly, the impact of affiliate investment on firm growth is confirmed for private-controlled firms only; whereas affiliate investment behaviors conducted by government-controlled firms do not play any significant role. The study also finds that profitability, government ownership and foreign ownership are significant dynamics for firm growth in the context of a transitional economy like Vietnam.

This paper makes several contributions to the literature. Theoretically, this study sheds light on the relationship between affiliate investment and firm growth as well as the impact of financial investment behaviors on firm growth in general. Methodologically, by focusing on affiliate investment in relation to three different dimensions of firm growth (i.e. sales growth, asset growth, net income growth), this study implies that any claims on the determinants of firm growth depend on how firm growth is measured. Empirically, this study provides new empirical evidence that private-controlled firms are more efficient than governmentcontrolled firms in terms of making affiliate investment. It also provides important implications about the determinants of growth rates of multinational corporations in the context of an Asian emerging economy.

This paper is structured as follows: Section 2 reviews the related literature on the determinants of firm growth. Section 3 provides background information on the research question. Section 4 presents the methodology and data employed in this research, including empirical models and variable measurement. Section 5 reports the results and discusses the implications of the research. Section 6 concludes the research and proposes some policy recommendations and possible future research.

\section{Review of Related Literature}

It is suggested in prior studies that determinants of firm growth come from a range of factors, depending on research perspectives and disciplines. Zhou and de Wit (2009) summarize that firm growth is determined by three following types of factors: 1) individual determinants, including personal traits of entrepreneurs, growth motivation, individual competencies, and personal background; 2) organizational determinants, including firm attributes, firm strategies, firm-specific resources, organizational structure, and dynamic capability; and 3) environmental determinants, including market dynamism, technology dynamism, munificence, hostility and competitive intensity. Affiliate investment is not explicitly documented in the above list. However, it can be argued that affiliate investment reflects firm strategies and firm-specific resources; and hence, it is potentially an important organizational determinant of firm growth. A significant body of previous literature has drawn on the firm size - firm growth relationship predicted in the well-known "Gibrat's law" (Gibrat, 1931), or the Law of Proportionate Effect. This law indicates that the growth rate of firms does not depend on firm size. However, empirical studies show mixed results of this relationship. While the results from the studies conducted by P. A. Geroski, Lazarova, Urga, and Walters (2003), Audretsch, 
Klomp, Santarelli, and Thurik (2004), and Rasiah, Tong, and Kim (2014) confirm the validity of this law, some other researchers do not support it (e.g. Adams, Andersson, Hardwick, \& Lindmark, 2014; Calvo, 2006). Furthermore, recent literature documents that this law holds partly, i.e. being valid for a particular group of firms only (e.g. Chih-Ping, 2016; Daunfeldt \& Elert, 2013; Tang, 2015; Xiu-fang, Xiao-jiao, \& Chao, 2013). Consequently, a recent trend in the literature is to test Gibrat's law using other potential determinants of firm growth; for instance, firm age, capital structure, profitability, financial risk, or ownership structure (Blandina \& Adelino, 2005; Paul A. Geroski \& Gugler, 2001; T. T. Nguyen \& Van Dijk, 2012; Yang \& Meyer, 2018).

Investment as a dynamic of firm growth has been studied from various perspectives, such as foreign direct investment (Chen \& Ku, 2000; Dimelis, 2005; Konings, 1997; Penrose, 1956), R\&D investment (Capasso et al., 2015; Coad \& Rao, 2010; Coad et al., 2016), or investment in information technology (Weill, 1992). There is a trend that prior scholars examine the impact of a particular form of affiliate investment on firm growth; for example, fixed asset investment (Cleary, 1999), investment in corporate venture capital (Dushnitsky \& Lenox, 2006; Engel \& Keilbach, 2007), and investment in working capital (Aktas et al., 2015), investment in equity ownership (Daily \& Thompson, 1994; Konings, 1997; Yang \& Meyer, 2018). However, there is a lack of empirical study on the role of affiliate investment on firm growth.

In the Vietnamese context, various aspects of firm performance have been examined in previous studies, such as those of Truong, Lanjouw, and Lensink (2006); Pham and Carlin (2008); Gainsborough (2009); Hidenobu and Lai Thi Phuong (2012); Phung and Mishra (2016). However, the link between affiliate investment and firm growth has not been explored in these studies.

\section{Overview of Firm Growth and Affiliate Investments in Vietnam}

The economic reform (doi moi policy) starting in the late 1980s and the ongoing privatization (equitization in the official term) of SOEs in Vietnam resulted in the booming of joint-stock companies where the firm's equity is partly or wholly owned by private shareholders. In the first phase of privatization (1989-1992), the number of SOEs in Vietnam dropped by half, from 12,300 to about 6,500 (Pham \& Carlin, 2008). In the most recent phase (2011-2015), about 500 enterprises were privatized. The average growth rate in the number of enterprises of all forms is respectively $22.26 \%$ and $7.4 \%$ in the periods $2006-2010$ and 2011-2014, totaling over 400,000 enterprises at the end of 2014 (GSO, 2016). Until recently, however, the state sector maintained its dominant role in the economy. This sector contributes up to $32.26 \%$ of GDP (GSO, 2016). It is also believed that the state sector is provided with greater access to resources such as land and finance (Nguyen \& Van Dijk, 2012). Nevertheless, the private sector outperforms the state sector. In comparison with SOEs, the statistics in GSO (2016) show that private-owned enterprises created an absolute majority of jobs offered by all types of enterprises in 2014 (58.9\% by domestic firms and $28.4 \%$ by foreign-owned firms). SOEs are also outperformed by private-owned firms in terms of growth in capital and profitability such as return on assets and returns on sales. In addition, the privatisation of SOEs and expansion of private firms in Vietnam have been supported by the operation of two national stock exchanges in Ho Chi Minh City (since 2000) and in Hanoi (since 2005). The total market capitalization of both exchanges is recorded at more than $94 \%$ of GDP in February $2020 .{ }^{1}$ Among nearly 700 listed companies, it should be noted that most of them are privatized SOEs. Affiliate investment was a quite common investment strategy among Vietnam's listed firms, in particular, listed SOEs, during the period from 2008-2015. Many firms attempted to expand capitals into other businesses, mostly in the form of subsidiaries, joint ventures and affiliated firms. They may hold a part or majority of common shares of such firms. Nevertheless, many of the investee companies did not operate in the main business lines of the investor companies. For example, a firm belonging to the oil and gas industry could invest in setting up new firms in the financial or basic materials industries. When Vietnam's stock market experienced a serious downturn during the period 2008-2010, it was observed that such financial investments suffered huge losses in market value. As a result, sharp reductions in profit were recognised in these firms' balance sheets as provisions, because it is required by law that they reserve a considerable amount of net income on provisions against potential financial losses. From corporate governance viewpoint, financial investment in the form of cross-shareholding between parent companies and subsidiary ones is associated with a range of problems, such as a lack of transparency in ownership structure; difficulty for shareholders and investors in understanding the company; poor consolidated accounting; and the ability to expropriate and ignore the rights of small individual shareholders (IFC, 2010). Under such circumstances, the Vietnamese government enacted a series of policy and regulatory documents that require that SOEs retreat capital investment from non-core business lines as aforementioned. ${ }^{2}$

\section{Methodology and Data}

\subsection{Firm Growth Measurement}

In the literature, different variables have been used to proxy firm growth, including growth in sales, assets, employment, market shares and profits (Coad, 2009; Coad et al., 2016; Gedajlovic \& Shapiro, 2002; Goddard, Molyneux, \& Wilson, 2004; Jang \&

\footnotetext{
${ }^{1}$ http://ssc.gov.vn/ubck/faces/vi/vimenu/vipages vithongtinthitruong/thongkettck/quymothitruong? adf.ctrl-state=59zf8k40z 211\& afrLoop=1544050059498000

${ }^{2}$ Decision 929/QĐ-TTg of the Prime Minister dated 17 July 2012 regarding the restructuring of SOEs; 2) Decree 71/2013/NĐ-CP of the government dated 11 July 2013 regarding state capital investment in businesses and financial management of enterprises wholly owned by the state; 3) Decree 15/NQ-CP of the government dated 6 March 2014 regarding some measures to speed up equalisation and retreat state capital in businesses; and 4) Decision 51/2014/QĐ-TTg of the Prime Minister dated 15 September 2014 regarding the retreat, sales of and registration of trading and listing on stock markets of SOEs.
} 
Park, 2011; Lee, 2014; T. T. Nguyen \& Van Dijk, 2012; Zhou \& de Wit, 2009). It is often that prior studies employ more than a single proxy of firm growth. Following prior authors, we employ in this study three alternative measures of firm growth, namely sales growth, asset growth, and net income growth. It can be argued that these variables reflect quite different dimensions of firm growth and hence, they should be treated separately to claim about one aspect of firm growth. The definitions of the firm growth proxies are presented below:

Sales growth (SG): We employed SG as the primary indicator of firm growth. SG is calculated as the percentage of change in net sales divided by one-year lagged net sales.

$$
S G_{i, t}=\frac{{\text { Net } \text { sales }_{i, t}-\text { Net }_{\text {sales }}, t-1}_{\text {Net } \text { sales }_{i, t-1}}}{100}
$$

Asset growth (AG): Growth in the firm's total assets is also a common indicator of firm growth in the literature. Asset growth is calculated as the percentage of change in the book value of total assets divided by the one-year lagged value of total assets of the firm.

$$
A G_{i, t}=\frac{\text { Book value of total assets }_{i, t}-\text { Book value of total assets }_{i, t-1}}{\text { Book value of total assets }} \text { tit-1 }_{100}
$$

Net income growth (NIG): Net income growth is another proxy for firm growth to reflect the growth in bottom-line net income in the profit-and-loss statement that belongs to shareholders of the firm. NIG is calculated as the percentage of change in net income divided by the one-year lagged value of net income.

$$
N I G_{i, t}=\frac{\text { Net }_{\text {income }_{i, t}-\text { Net }_{\text {income }}, t-1}}{\text { Net } \text { income }_{i, t-1}} \times 100
$$

\subsection{Dynamics of Firm Growth}

Based on prior literature and for the purpose of this paper, we specify three main groups of explanatory variables in the empirical models, namely prior firm growth, affiliate investment and control variables.

\section{Prior firm growth}

It is likely that firm growth is dynamic in nature; that is, the existing firm growth is affected by prior firm growth. Recent studies have reported that the dynamic effect of past firm growth is significantly either positive or negative, depending on the time lags used in the study (Jang \& Park, 2011; Lee, 2014). In this paper, we will control for the impact of prior firm growth in a dynamic model, where prior firm growth is calculated as one-year lagged firm growth $\left(\mathrm{SG}_{\mathrm{t}-1}, \mathrm{AG}_{\mathrm{t}-1}\right.$, and $\mathrm{NPG}_{\mathrm{t}-1}$ respectively for each measure of firm growth).

\section{Affiliate investment}

Affiliate investment (AFIN) is the main variable of interest since the main purpose of this study is to test for the effect of investment in subsidiaries, joint ventures and affiliates (affiliate investment) on firm growth. AFIN is calculated as investments in subsidiaries, joint ventures and affiliates scaled by total assets.

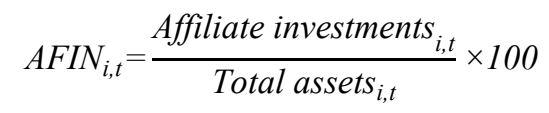

In the balance sheets of the Vietnamese listed firms, AFIN is presented as a component of non-current assets, which is termed 'long-term financial investment'. This entry covers all forms of financial investment into subsidiaries, joint ventures and affiliates. According to International Financial Reporting Standards (IFRS) and International Accounting Standards (IAS), a subsidiary is defined as "An entity that is controlled by another entity" (IFRS 10). A joint venture is defined as "A joint arrangement whereby the parties that have joint control of the arrangement have rights to the net assets of the arrangement", and "An associate is an entity over which the investor has significant influence" (IAS 28). Such type of investment can be referred to as the expansion of the firm into related or unrelated industries to pursue growth and profit opportunities; whereby the firm's financial, physical and intangible resources are leveraged (Kim \& Rasheed, 2014). The higher value of affiliate investment may also indicate the higher degree of diversification of the firm into other businesses. Therefore, it is expected that AFIN has significant impacts on at least one measure of firm growth employed in this study.

\section{Control variables}

Firm size (SIZE) is included as a control variable since it is a classical proxy to be tested in the growth-size relationship according to Gibrat's law (Gibrat, 1931). It is likely that firm growth is negatively determined by firm size in the Vietnamese context, as 
reported in T. N. Nguyen (2013). SIZE is defined as the natural logarithm of the firm's total sales (Jang \& Park, 2011; Lee, 2014).

Government ownership (GO) and Foreign ownership (FO): Given the country-specific characteristics of Vietnam as discussed in Section 3, we employ GO and FO as two additional control variables to capture the influence of ownership structure on firm growth. Theoretically, ownership structure can influence firm performance, including firm growth, because the owners of the firm have different levels of power, incentives, and ability to monitor managers, while they also differ in goals for involving in the firm (Douma, George, \& Kabir, 2006). Empirical studies also postulate the impact of ownership structure on firm growth (Daily \& Thompson, 1994; Konings, 1997; Yang \& Meyer, 2018). GO is calculated as the ratio of common equity owned by the government over the total common equity of a firm, and FOR is calculated as the ratio of common equity held by foreign investors over the total common equity of a firm.

Firm age (AGE) is defined as the difference between the observed year and the initial year of listing on stock exchanges. It is generally accepted in the literature that the growth rates of a firm tend to diminish over time as the firm approaches the mature phase of the business cycle; hence, we expect that AGE is negatively related to firm growth.

Profitability (PRO) is employed to capture the impact of profitability on firm growth. PRO is defined as the ratio of return on assets (ROA), where the return is calculated as earnings before interest and taxes over the total asset of a firm (EBIT/Assets). In the literature, there is evidence that firm growth and profitability are mutually determined (e.g. Chadha \& Sharma, 2015; Federico \& Capelleras, 2015; Gedajlovic \& Shapiro, 2002; Jang \& Park, 2011; Lee, 2014; Rasiah et al., 2014). Therefore, the problem of simultaneous endogeneity between firm growth and profitability may exist and can be controlled by using an appropriate model specification and estimation methods. Following prior authors, we expect that PRO has a positive impact on firm growth.

Another control variable is financial leverage (LEV). It is defined as the ratio of total liabilities over total assets of the firm. Financial leverage represents a source of external funding and financial resources of the firm, which may boost the growth rate of the firm. It is also suggested in the literature that firm growth is positively associated with access to financial resources (Zhou $\&$ de Wit, 2009). Thus, it is expected that LEV has a positive impact on firm growth in this paper.

\subsection{Empirical Models and Estimation Methods}

Following previous studies (e.g. Jang \& Park, 2011; Lee, 2014; Rasiah et al., 2014; Roberta, Ivan, \& Emiliano, 2014), and for the purpose of this study, we estimate two separate empirical models in order to analyse the effects of affiliate investment on firm growth. First, a static model that does not account for the dynamic effect of past firm growth on current firm growth is employed as below:

$$
\text { Firm growth }_{i t}=\beta_{0}+\beta_{1} \text { AFIN }_{i, t-1}+\beta_{2} \text { AFIN }_{i, t-2}+\beta_{3} \text { Control }_{i, t-1}+\varepsilon_{i t}
$$

where the $i$ and $t$ subscripts denote firm and year. AFIN denotes affiliate investment, Control refers to control variables, including firm size, government ownership, foreign ownership, firm age, profitability, financial leverage, and year dummies. $\beta$ and $\varepsilon$ denote parameters and error term, respectively. It is likely that current-year firm growth is affected by affiliate investment and other influencing factors in the previous year. Following Lee (2014), we specify two-period lags for the main variable of interest (AFIN, at t-1 and t-2) to obtain a relatively deeper insight into the effect of affiliate investment on firm growth. Adding further time lags reduces the number of observations. All control variables of firm growth are treated at one-year lags. Using lagged terms of independent variables is also to mitigate potential simultaneous endogeneity between firm growth and explanatory variables. Unobserved firm fixed effects are potential in Model 1 because firms are not homogenous. The time-invariant component in the fixed-effects model captures the unobserved heterogeneity of firms and allows a limited form of endogeneity since it is correlated with the explanatory variables (Cameron \& Trivedi, 2010). Thus, the fixed-effects estimation is employed using a White heteroskedasticity-consistent covariance estimator to control for unobserved heterogeneity across individual firms. Year dummies are also included in Model 1 to control for the time effects. We also test the effect of affiliate investment in a dynamic model, where the dynamic effect of firm growth is controlled for, as specified in the model below.

$$
\text { Firm growth }_{i t}=\beta_{0}+\lambda_{i} \text { Firm growth }_{i, t-1}+\beta_{1 A} A \text { FIN }_{i, t-1}+\beta_{2} A \text { FIN }_{i, t-2}+\beta_{3} \operatorname{control}_{i, t-1}+\varepsilon_{i t}
$$

where the $i$ and $t$ subscripts denote firm and year. AFIN denotes affiliate investment, control refers to control variables, including firm size, government ownership, foreign ownership, firm age, profitability, financial leverage, industry dummies and year dummies. $\lambda, \beta$ denote parameters, and $\varepsilon$ error term, respectively. A dynamic system GMM estimator is employed for Model 2 since the lagged values of the dependent variable is present in the model. The dynamic GMM panel specifications can overcome the problems of the dynamic effects and endogeneity in the explanatory variables by employing a valid set of internal instruments, hence producing unbiased and consistent estimates (Arellano \& Bond, 1991; Arellano \& Bover, 1995; Blundell \& Bond, 1998). A two-step dynamic system GMM estimator is opted for estimating Model 2. The two-step procedure is considered 
more efficient than the one-step procedure (Roodman, 2009). ${ }^{2}$ Additionally, system GMM regressors are more efficient than difference GMM regressors because of the increased number of instruments as a result of the addition of the level equation.

According to Roodman (2009), one assumption for the use of system GMM regression is that there is no correlation across individuals (firms) in the idiosyncratic disturbances, and the inclusion of time dummies can make this assumption more likely to hold. Therefore, year dummy variables are added in Model 2 to control for the time effects. In addition, industry dummies are also added to account for the industry fixed effects. Based on a split-sample method, we also test the above models with two sub-sample datasets which are divided by the ratio of government ownership: A sub-sample of private-controlled firms is used if government ownership is less than or equal to 50\%, and a sub-sample of government-controlled ownership where government ownership accounts for more than $50 \%$ of the total common equity of the firms. Since affiliate investment is a common practice among SOEs in Vietnam during the time period of study, it is reasonable to use such split samples to compare and obtain a clear understanding of the issue for government-controlled firms in comparison with private-controlled firms. Hence, additional insights into the effect of affiliate investment on firm growth are provided. Similar estimation methods performed for the full sample are applied to these two sub-samples.

\subsection{Data Sample}

This research collects sample data from a leading business and financial data vendor in Vietnam - FiinGroup. ${ }^{3}$ The advantage of this data collection is that it can be cross-checked for accuracy from different sources on the Vietnamese stock markets where the firms' financial statements and annual reports are disclosed, such as the websites of listed companies, stock exchanges, and securities firms. Specifically, the dataset covers all listed firms in Vietnam for 8 years from 2008-2015 (on Hanoi Stock Exchange and Hochiminh Stock Exchange). ${ }^{4}$ The exceptions are the UpCOM board of the HNX (for unlisted public companies) and financial companies (i.e. securities firms, insurance companies and commercial banks). In total, a balanced panel data sample is obtained with 2056 firm-year observations (257 firms over 8 years). The starting year of 2008 is selected because the Securities Law of Vietnam came into effect one year earlier in 2007. As a result, it is possible that the quality of mandatory information disclosure of listed firms is enhanced. In addition, the international financial reporting and accounting standards applicable to listed firms on Vietnam's stock market were largely adopted since 2008 in Vietnam. In order to eliminate potential biases caused by outliers, all variables are winsorized at 1 percent level on both sides of the distribution. The summary statistics of all variables in the full sample and in two split samples are respectively presented in Table 1 and Table 2 below.

Table 1

Summary statistics of variables (full sample)

\begin{tabular}{|c|c|c|c|c|c|c|}
\hline Denotation & Variable & Obs & Mean & Std.Dev. & Min & Max \\
\hline SG & Sale growth & 2,056 & 15.62 & 37.54 & -62.63 & 193.52 \\
\hline $\mathbf{A G}$ & Asset growth & 2,056 & 14.40 & 26.55 & -31.15 & 137.70 \\
\hline NIG & Net income growth & 2,056 & 13.49 & 253.02 & $-1,385.73$ & $1,391.43$ \\
\hline AFIN & Affiliate investment & 2,056 & 5.62 & 8.79 & 0.00 & 45.59 \\
\hline SIZE & Firm size & 2,056 & 26.92 & 1.46 & 23.43 & 30.63 \\
\hline GO & Government ownership & 2,056 & 27.02 & 21.98 & 0.00 & 73.15 \\
\hline FO & Foreign ownership & 2,056 & 10.68 & 13.75 & 0.01 & 49.00 \\
\hline AGE & Firm age & 2,056 & 13.28 & 2.80 & 8.00 & 21.00 \\
\hline PRO & Profitability & 2,056 & 11.70 & 8.53 & -4.62 & 39.84 \\
\hline LEV & Financial leverage & 2,056 & 50.24 & 21.73 & 5.81 & 86.44 \\
\hline
\end{tabular}

Notes: This table reports the summary of statistics of the full data sample employed in this study. All variables are measured in percentage units, except for SIZE in natural logarithms of sales, and AGE in years.

Table 2

Summary statistics of variables (split samples)

\begin{tabular}{cccc|cc}
\hline Variable & $\begin{array}{c}\text { Private-controlled firms (<=50\% government ownership) } \\
\text { Obs }\end{array}$ & $\begin{array}{c}\text { Mean } \\
\text { Std.Dev. }\end{array}$ & \multicolumn{2}{c}{$\begin{array}{c}\text { Government-controlled firms (>50\% government ownership) } \\
\text { Obs }\end{array}$} & $\begin{array}{c}\text { Mean } \\
\text { Std.Dev. }\end{array}$ \\
\hline SG & 1,479 & 16.831 & 39.718 & 577 & 12.499 \\
AG & 1,479 & 15.671 & 27.503 & 577 & 11.145 \\
NIG & 1,479 & 12.778 & 270.103 & 577 & 15.321 \\
AFIN & 1,479 & 6.146 & 9.374 & 577 & 4.288 \\
SIZE & 1,479 & 26.798 & 1.476 & 577 & 27.221 \\
GO & 1,479 & 16.329 & 15.807 & 577 & 54.434 \\
FO & 1,479 & 12.391 & 14.990 & 577 & 6.283 \\
AGE & 1,479 & 13.452 & 2.888 & 577 & 1.38 \\
PRO & 1,479 & 11.280 & 8.441 & 577 & 12.853 \\
LEV & 1,479 & 48.113 & 21.040 & 5.957 & 12.780 \\
\hline
\end{tabular}

Notes: This table reports a summary of the main statistics of two sub-samples. All variables are measured in percentage units, except for SIZE in natural logarithms of sales, and AGE in years.

\footnotetext{
${ }^{3}$ http://fiingroup.vn/

4 www.hsx.vn; www.hnx.vn
} 
H. N. Pham and B. Kalyebara /Accounting 6 (2020)

The pairwise correlation matrix is illustrated in Table 3. It should be noted that the correlation coefficients are calculated on the basis of the current-year period (at time $t$ ) of variables. It is shown that all coefficients of correlation among explanatory variables are small. Among the main variables of interest, affiliate investment (AFIN) shows little and insignificant correlations with three firm growth measures employed in this research (SG, AG and NIG). This is a preliminary sign that affiliate investment does not have a contemporaneous impact on firm growth, suggesting that deeper time lags be used to explore the potential impacts of past AFIN on current firm growth.

Table 3

Pairwise correlation matrix of variables (full sample at time t)

\begin{tabular}{|c|c|c|c|c|c|c|c|}
\hline & SG & $\mathbf{A G}$ & NIG & AFIN & SIZE & AGE & PRO \\
\hline SG & 1 & & & & & & \\
\hline $\mathbf{A G}$ & $0.3354 *$ & 1 & & & & & \\
\hline NIG & $0.2048 *$ & $0.1419^{*}$ & 1 & & & & \\
\hline AFIN & 0.0236 & -0.0031 & 0.0156 & 1 & & & \\
\hline SIZE & $0.1417 *$ & $0.1075^{*}$ & $0.0455^{*}$ & $-0.0417^{*}$ & 1 & & \\
\hline AGE & $-0.1353^{*}$ & $-0.2026^{*}$ & -0.0266 & $0.0532 *$ & $0.0728 *$ & 1 & \\
\hline PRO & $0.1332 *$ & 0.0317 & $0.1162 *$ & $-0.1943^{*}$ & $0.1792 *$ & $-0.1642 *$ & 1 \\
\hline LEV & $0.0806^{*}$ & $0.1594^{*}$ & -0.0277 & $-0.1980 *$ & $0.3201 *$ & $-0.1577 *$ & $-0.1924 *$ \\
\hline FO & 0.0252 & 0.0299 & 0.0153 & $0.1299 *$ & $0.3173 *$ & $0.1947 *$ & $0.2039 *$ \\
\hline \multirow[t]{2}{*}{ GO } & $-0.0637^{*}$ & $-0.0899 *$ & -0.00550 & $-0.1717^{*}$ & $0.0798 *$ & $-0.0601 *$ & $0.1480 *$ \\
\hline & LEV & FO & GO & & & & \\
\hline LEV & 1 & & & & & & \\
\hline FO & $-0.2744 *$ & 1 & & & & & \\
\hline GO & $0.1177^{*}$ & $-0.1986^{*}$ & 1 & & & & \\
\hline
\end{tabular}

The above correlation matrix presents the static correlations (at time $t$ ) among all variables. We further detect the potential noncontemporaneous correlations among the main variables using deeper time lags $(t-1$ and $t-2)$ in the forms of scatter plots. The full data sample is presented graphically in Figures 1-3 below. As the main concern is about the effect of affiliate investment, the graphs depict the relationship between affiliate investment and each measure of firm growth using one-year lagged ( $\mathrm{t}-1)$ and two-year lagged ( $\mathrm{t}-2)$ affiliate investment on the horizontal axis, respectively. It appears that the correlation between affiliate investment and sales growth is very low (Figure 1), but it is fairly improved with regard to asset growth (Fig. 2). Fig. 3 suggests that the positive relationship between affiliate investment and net income growth is quite clear.
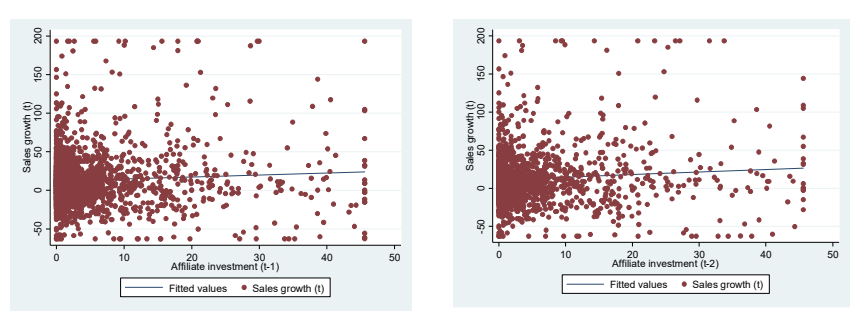

Fig. 1. Sales growth - affiliate investment relationship at t-1 (left) and t-2 (right)

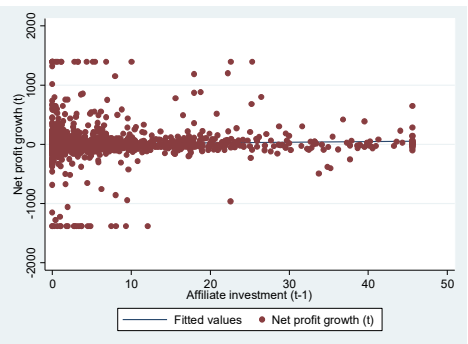

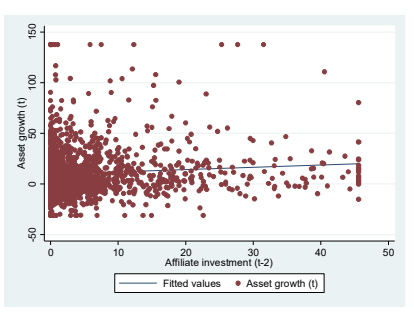

Fig. 2. Asset growth - affiliate investment relationship at $t-1$ (left) and t-2 (right)

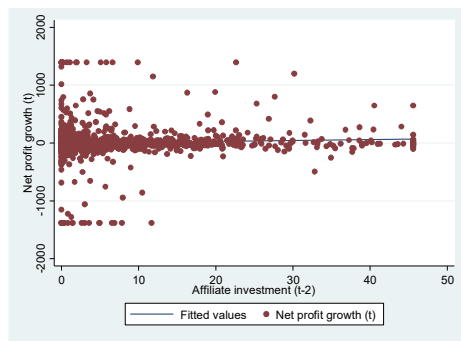

Fig. 3. Net income growth - affiliate investment relationship at t-1 (left) and t-2 (right)

\section{Results and discussion}

Tables 4-6 below present the regression results of the empirical models for the relationship between affiliate investment and other control variables on firm growth. 


\section{Table 4}

Fixed-effect estimation of static model (full sample)

\begin{tabular}{|c|c|c|c|}
\hline Dependent variable & SG & AG & NIG \\
\hline $\mathbf{A F I N}_{\mathrm{t}-1}$ & $\begin{array}{l}0.140 \\
(0.501)\end{array}$ & $\begin{array}{l}0.617 \\
(0.242)^{* *}\end{array}$ & $\begin{array}{l}-1.866 \\
(2.012)\end{array}$ \\
\hline $\operatorname{AFIN}_{t-2}$ & $\begin{array}{l}0.047 \\
(0.310)\end{array}$ & $\begin{array}{l}0.404 \\
(0.180)^{* *}\end{array}$ & $\begin{array}{l}4.738 \\
(1.493)^{* * *}\end{array}$ \\
\hline \multicolumn{4}{|l|}{$\mathbf{S G}_{\mathrm{t}-1}$} \\
\hline \multicolumn{4}{|l|}{$\mathbf{A} \mathbf{G}_{\mathrm{t}-1}$} \\
\hline \multicolumn{4}{|l|}{$\mathbf{N I G}_{\mathrm{t}-1}$} \\
\hline SIZE $_{t-1}$ & $\begin{array}{l}-48.225 \\
(6.248)^{* * *}\end{array}$ & $\begin{array}{l}-7.681 \\
(3.010)^{* *}\end{array}$ & $\begin{array}{l}-13.472 \\
(23.032)\end{array}$ \\
\hline $\mathbf{A G E}_{t-1}$ & $\begin{array}{l}-2.915 \\
(5.554)\end{array}$ & $\begin{array}{l}-3.214 \\
(7.646)\end{array}$ & $\begin{array}{l}-92.583 \\
(74.504)\end{array}$ \\
\hline $\mathbf{P R O}_{t-1}$ & $\begin{array}{l}-0.053 \\
(0.300)\end{array}$ & $\begin{array}{l}0.674 \\
(0.217)^{* * *}\end{array}$ & $\begin{array}{l}-1.915 \\
(1.398)\end{array}$ \\
\hline $\mathbf{L E V}_{t-1}$ & $\begin{array}{l}0.464 \\
(0.154)^{* * *}\end{array}$ & $\begin{array}{l}-0.385 \\
(0.136)^{* * *}\end{array}$ & $\begin{array}{l}-0.376 \\
(0.934)\end{array}$ \\
\hline $\mathbf{F O}_{\mathrm{t}-1}$ & $\begin{array}{l}0.320 \\
(0.225)\end{array}$ & $\begin{array}{l}-0.241 \\
(0.134)^{*}\end{array}$ & $\begin{array}{l}-2.245 \\
(1.593)\end{array}$ \\
\hline $\mathbf{G O}_{t-1}$ & $\begin{array}{l}-0.175 \\
(0.100)^{*}\end{array}$ & $\begin{array}{l}-0.073 \\
(0.126)\end{array}$ & $\begin{array}{l}0.619 \\
(0.732)\end{array}$ \\
\hline _cons & $\begin{array}{l}1,340.490 \\
(189.161)^{* * *}\end{array}$ & $\begin{array}{l}281.992 \\
(142.376)^{* *}\end{array}$ & $\begin{array}{l}1,861.516 \\
(1,313.846)\end{array}$ \\
\hline Time effect & Yes & Yes & Yes \\
\hline$N$ & 1,542 & 1,542 & 1,542 \\
\hline$R^{2}$ & 0.25 & 0.17 & 0.02 \\
\hline
\end{tabular}

Notes: The statistical significance at the $10 \%, 5 \%$ and $1 \%$ levels are indicated by $*{ }^{* *}$ and ${ }^{* * *}$, respectively.

\section{Table 5}

System GMM estimation of dynamic model (full sample)

\begin{tabular}{|c|c|c|c|}
\hline Dependent variable & SG & $\mathbf{A G}$ & NIG \\
\hline $\operatorname{AFIN}_{t-1}$ & $\begin{array}{l}-0.080 \\
(0.399)\end{array}$ & $\begin{array}{l}0.538 \\
(0.215)^{* *}\end{array}$ & $\begin{array}{c}0.948 \\
(1.262)\end{array}$ \\
\hline $\mathbf{A F I N}_{\mathrm{t}-2}$ & $\begin{array}{c}0.187 \\
(0.340)\end{array}$ & $\begin{array}{l}0.019 \\
(0.159)\end{array}$ & $\begin{array}{l}3.103 \\
(1.451)^{* *}\end{array}$ \\
\hline $\mathbf{S G}_{\mathrm{t}-1}$ & $\begin{array}{l}0.062 \\
(0.037)^{*}\end{array}$ & & \\
\hline $\mathbf{A} \mathbf{G}_{\mathrm{t}-1}$ & & $\begin{array}{l}0.176 \\
(0.042) * * *\end{array}$ & \\
\hline $\mathbf{N I G}_{t-1}$ & & & $\begin{array}{c}0.026 \\
(0.022)\end{array}$ \\
\hline SIZE $_{t-1}$ & $\begin{array}{l}-6.508 \\
(2.724)^{* *}\end{array}$ & $\begin{array}{c}2.092 \\
(1.321)\end{array}$ & $\begin{array}{c}7.319 \\
(11.858)\end{array}$ \\
\hline $\mathbf{A G E}_{\mathrm{t}-1}$ & $\begin{array}{l}-0.127 \\
(0.844)\end{array}$ & $\begin{array}{l}-0.519 \\
(0.483)\end{array}$ & $\begin{array}{l}-3.116 \\
(4.058)\end{array}$ \\
\hline $\mathbf{P R O}_{\mathrm{t}-1}$ & $\begin{array}{l}-0.423 \\
(0.268)\end{array}$ & $\begin{array}{l}0.541 \\
(0.182) * * *\end{array}$ & $\begin{array}{l}1.797 \\
(1.080)^{*}\end{array}$ \\
\hline $\mathbf{L E V}_{\mathrm{t}-1}$ & $\begin{array}{l}0.308 \\
(0.129)^{* *}\end{array}$ & $\begin{array}{l}-0.095 \\
(0.093)\end{array}$ & $\begin{array}{c}0.539 \\
(0.712)\end{array}$ \\
\hline $\mathbf{F O}_{\mathrm{t}-1}$ & $\begin{array}{l}0.394 \\
(0.169)^{* *}\end{array}$ & $\begin{array}{l}-0.198 \\
(0.105)^{*}\end{array}$ & $\begin{array}{l}-0.554 \\
(0.982)\end{array}$ \\
\hline $\mathbf{G O}_{\mathrm{t}-1}$ & $\begin{array}{l}-0.216 \\
(0.093)^{* *}\end{array}$ & $\begin{array}{l}-0.220 \\
(0.070)^{* * *}\end{array}$ & $\begin{array}{c}0.122 \\
(0.474)\end{array}$ \\
\hline _cons & $\begin{array}{c}0.000 \\
(0.000)\end{array}$ & $\begin{array}{c}0.000 \\
(0.000)\end{array}$ & $\begin{array}{l}-227.776 \\
(333.205)\end{array}$ \\
\hline Time effect & Yes & Yes & Yes \\
\hline Industry effect & Yes & Yes & Yes \\
\hline$N$ & 1,542 & 1,542 & 1,542 \\
\hline AR(1) & 0.00 & 0.00 & 0.00 \\
\hline $\operatorname{AR}(2)$ & 0.25 & 0.50 & 0.21 \\
\hline Hansen test & 0.06 & 0.21 & 0.38 \\
\hline Diff.in.Han test & 0.56 & 0.90 & 0.89 \\
\hline
\end{tabular}

Notes: The statistical significance at the $10 \%, 5 \%$ and $1 \%$ levels are indicated by $*{ }^{* *}$ and ${ }^{* * *}$, respectively. 


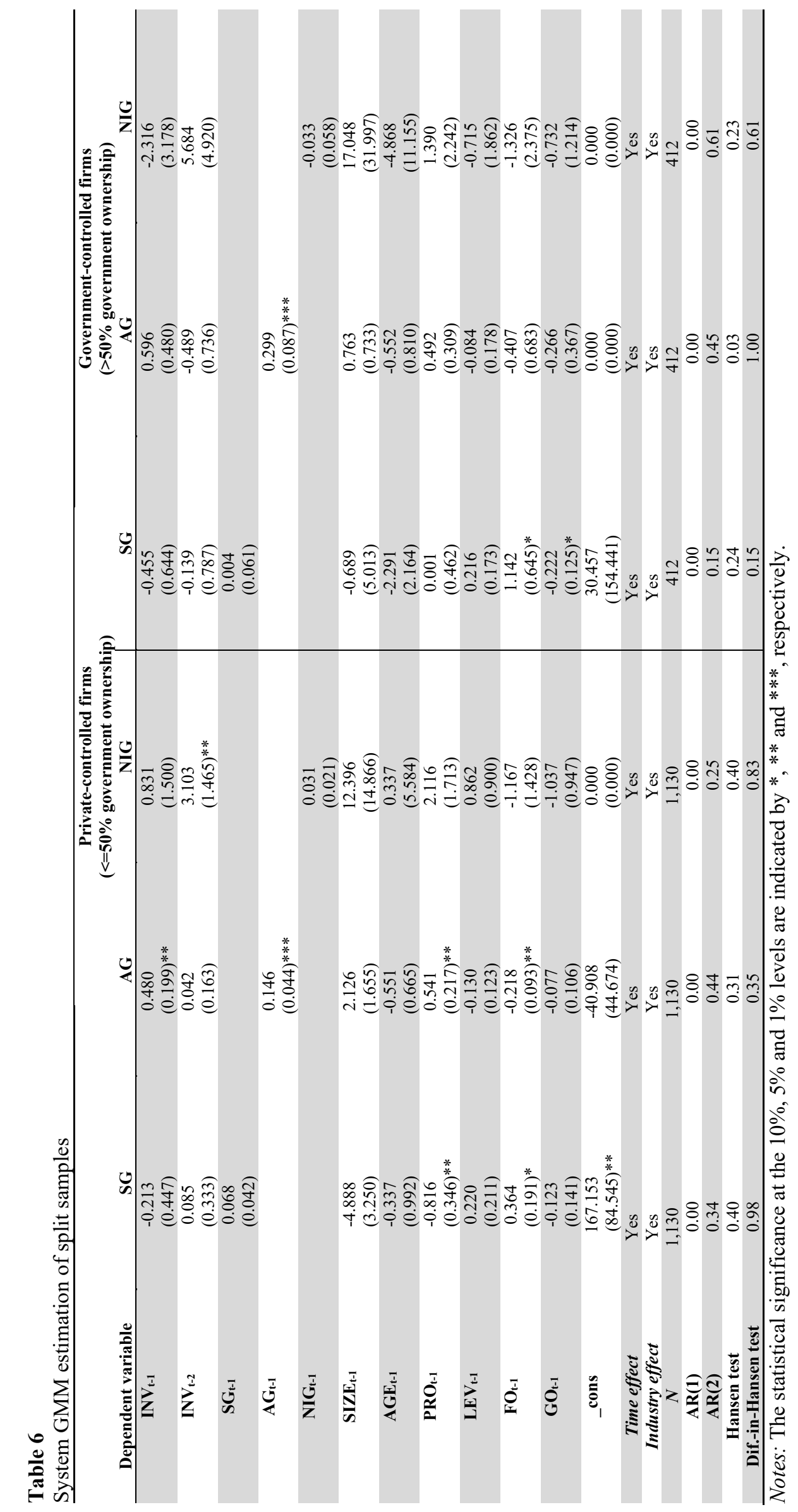




\subsection{Affiliate Investment and Firm Growth}

The affiliate investment at time $t-1$ shows a significantly positive relationship with the current-year asset growth. This finding is consistent in both FE and GMM estimations of the full sample and the GMM estimation of the private-controlled sample. That is, the higher level of affiliate investment (in the form of capital investment into subsidiaries, joint ventures and affiliates) is associated with the higher asset growth rate of the firm. Holding other variables unchanged, an increase of $1 \%$ in affiliate investment in the prior year is correlated to an expansion of around $0.5 \%$ in total assets in the current year. For those firms targeting expanding asset values, therefore, affiliate investment may be an appropriate option. Likewise, affiliate investment at time $t-2$ is found to have a strong and significantly positive impact on net income growth in the current year. A $1 \%$ increase in affiliate investment this year is associated with more than 3\% improvement in net income this year. It is possible that intensifying affiliate investment this year has an immediate impact on the asset growth rate in the next year, whereas it takes a relatively long time for affiliate investment to improve the firm profit. More importantly, further estimations for split samples reveal that the above-mentioned positive effects are valid for private-controlled firms only. As for government-controlled firms, on the contrary, affiliate investment does not show any significant impact on all dimensions of firm growth employed in this research. Such non-significant impacts are found at both time lags (i.e. at times $t$ - 1 and $t$-2). The results for private firms can be explained by the 'alignment of interest effect' hypothesis, which postulates that the higher the level of managerial ownership, the better firm performance is (Jensen \& Meckling, 1976). It is also likely that private-owned firms perform better than governmentowned firms in terms of employing aggressive actions for business growth (Yang \& Meyer, 2018). Whereas, the insignificant impact of affiliate investment performed by government-controlled firms shows that the SOEs are less efficient than private ones. This evidence is consistent with the negative view about government ownership with regard to firm performance in privatization literature (Djankov \& Murrell, 2002; Megginson, Nash, \& Randenborgh, 2012). It is also consistent with the result of government ownership (GO). As can be seen from Tables 4-6, government ownership shows a negative effect on both dimensions of firm growth (i.e. sales growth and asset growth), while there is no significant impact on net income growth. This result is particularly valid when we examine more closely at the government-controlled firms: an increase of 1 percent in the previous-year government ownership is related to a decline of more than 2 percent in sales growth, holding all other variables unchanged. It is likely that government investors do not exercise effective monitoring roles over the invested stakes at their subsidiaries, joint ventures and affiliated firms. There is a potential principal-agent problem if managers of SOEs are appointed by the government to act as the agents of government ownership at the firm. In addition, government investors may not have enough incentives for making profits from investments. In theory, the government shareholders may place more emphasis on the 'social service assignment principle' rather than purely on 'shareholder value interests' (Kankaanpää, Oulasvirta, \& Wacker, 2014). There is thus a potential conflict between the social objective of the government and the profit objective of the firm (Sun $\&$ Feng, 2004). The findings on the inefficiency of investment by the government enrich the literature on investment behaviors by the public finance decision-makers. On the one hand, this paper suggests the inefficiency of investment by the government applicable to government-controlled firms as investor companies. From an investee company's perspective (i.e. the firms invested by the government), on the other hand, recent studies also report that government venture capital-backed firms are less efficient than private venture capital-backed firms (Alperovych, Hübner, \& Lobet, 2015; Cumming et al., 2017). Furthermore, it is found that affiliate investment activities do not significantly influence the sales growth of both types of firms. Over the past decade, a large number of the Vietnamese listed firms utilized a high ratio of affiliate investment (officially termed as a longterm financial investment) in other businesses, many of which do not belong to the core business lines of the firms. While such high investment stakes might help the firms expand the total value of assets, they are exposed to market risks or capital losses at the times of stock market downturns. It is also likely that the firms suffered from less financial resources for accelerating sales in their core business areas as a consequence of intensifying affiliate investment. Therefore, these results provide empirical evidence for the regulatory policies that request the partial or complete withdrawal of capital investment by governmentcontrolled firms from subsidiaries, joint ventures and affiliates.

\subsection{Other Dynamics of Firm Growth}

Prior firm growth: Previous growth rates show mixed results, which are subject to firm growth measures. On the one hand, we find consistent and strong evidence that the previous-year asset growth rate is a strong determinant of the current-year asset growth in all the GMM estimations for the dynamic models. Specifically, an increase of 1\% in the firm's assets in the previous year is followed by asset growth rates from $0.15 \%-0.3 \%$ in the current year. On the other hand, the lagging effects of prior sales growth and prior net income growth are not statistically significant for both private and government-controlled firms, albeit the previous-year sales growth shows a significant impact in the full sample. It suggests that previous-year growth rates do not have any significant explanatory power for sales growth and net income growth in the case of Vietnam's listed firms.

Firm size: As already mentioned, it is widely known that Gibrat's law (Gibrat, 1931) predicts the independence of firm growth from firm size. This law has been tested in many earlier studies; and interestingly, there exist both supporting and counterevidence on this law. In this paper, we find that Gibrat's law is valid for the Vietnamese listed firms. At least, there is strong evidence that firm size is independent of both asset growth and net income growth. As shown in Table 4, the effect of prior firm 
size on such two growth dimensions is not statistically significant, and these results remain similar across all estimation methods. If firm growth is measured in sales, firm size shows a strong negative relationship with firm sales growth in the full sample only. However, this impact is no longer significant if two types of firms are tested separately as reported in Tables 5-6. It indicates that firm size does not explain the growth of the listed firm in Vietnam, and this is strong evidence to support the validity of Gibrat's law. This finding is in sharp contrast with those reported by T. N. Nguyen (2013) that Gibrat's law is rejected for the Vietnamese firms in the commercial-service sector. It is perhaps due to the coverage of sectors of the firms and the estimation method. While Nguyen tests the contemporaneous firm size - firm growth relationship for the commercial-service sector only, this research accounts for the listed firms of all sectors on Vietnam's stock market. This research differs in investigating the issue from a dynamic perspective.

Firm age: Regarding the impact of other variables, we find that firm growth of all forms is exogenous to firm age. It is shown in Table 4 that the expansion in all growth measures of the firm is not significantly determined by how many years the firm is on business. The negative signs of the coefficients on firm age are consistent with some prior studies using the Vietnamese database, such as T. T. Nguyen and Van Dijk (2012).

Firm Profitability: Similar to asset growth, the estimated results for firm profitability is quite consistent across different estimations for private-controlled firms. Specifically, it is indicated that prior profitability highly contributes to expanding the private firm's asset base in the current period, but it has a diminishing impact on sales growth. In addition, the magnitude of influence of profitability on asset growth is stronger than that on sales growth. Holding other things constant, a previous-year increase of $1 \%$ in ROA ratio is correlated with the acceleration of more than $0.5 \%$ in the current-year asset growth rate.

It might be that the Vietnamese listed firms tend to use financial resources (i.e. asset and profit) more efficiently for increasing asset value than for improving sales or profit. Prior authors also show that previous-year financial performance has a positive effect on current-year firm growth (Jang \& Park, 2011; Zhou \& de Wit, 2009). We further find that the positive effects of prior asset growth and profitability depend on how firm growth is measured. Taken together, it can be argued that improving the firm's asset growth and profitability in the previous fiscal year may be helpful channels, among others, to achieve the goal of corporate asset value maximization.

Financial leverage: shows a significantly positive impact on sales growth and a negative impact on asset growth. The results are consistent in both FE and GMM in the full data sample. However, the effects of financial leverage on firm growth become insignificant when two subsets of the firms are estimated. These findings indicate that financial leverage may not be a significant driving force for improving firm growth in the Vietnamese context. It suggests that the listed firms should not rely on external sources of funding to boost the expansion in both sales and assets, particularly for accelerating net income growth.

Foreign ownership: Foreign ownership shows a significantly positive impact on sales growth, and this finding is consistent in all estimation methods, including static and dynamic models. Interestingly, while foreign ownership appears to improve sales growth, it is found to have a negative impact on asset growth, particularly in private-controlled firms. Precisely, foreign ownership is estimated to be significantly negatively related to the asset growth rate of private firms at the $5 \%$ significance level. An increase of $1 \%$ in foreign ownership is associated with a drop of more than $0.2 \%$ in asset growth. The sign of the coefficient on foreign ownership is also negative for net income growth, but this effect is not statistically significant. In the context of an emerging stock market like Vietnam, the increase of foreign shareholdings in the listed firms can be a positive signal to the market in terms of improved credit rating and long-term growth, resulting in attracting more business partners, gaining larger market shares and hence raising sales volume. At the same time, it is likely that the presence of foreign shareholders strengthens the monitoring role of shareholders while restraining the firms' discretion to expand assets through investing in risky projects.

\subsection{Robustness Checks}

Two further tests are conducted to check for the robustness of the research methods used and the reliability of results as reported above. First, firm size is conventionally a variable of interest in investigating the determinants of firm growth, in particular for testing Gibrat's law. Therefore, another proxy of firm size (SIZE2) is employed in this research to check for the robustness of the results reported above. SIZE2 is measured as the natural logarithm of the market capitalization of the firm. Second, firm age (AGE) is removed from both Model 1 and Model 2. Under such new treatments of variables, estimated results are entirely consistent.

\section{Conclusion}

Several main results of this research are summarized as follows. First, we have shown that investment in subsidiaries, joint ventures and affiliates (affiliate investment) did matter with regards to firm growth since the former had significantly positive dynamic effects on relevant measures of the latter. Second, there was strong evidence that the positive impact of affiliate investment was valid for private-controlled firms instead of government-controlled firms. Furthermore, this study has found that profitability, government ownership and foreign ownership were significant dynamics for firm growth in the context of a transitional and emerging market. This study makes a theoretical contribution to the literature by shedding light upon the relationship between affiliate investment and firm growth as well as the impact of corporate investment behaviors on firm 
growth in general. It indicates that long-term financial investment in the form of affiliate investment in the previous years plays a significantly positive role in accelerating firm growth in the current year. However, it depends on whether ownership concentration at the firm is in the hands of private shareholders or government shareholders. Methodologically, by focusing on affiliate investment in relation to three different dimensions of firm growth (i.e. sales growth, asset growth, net income growth), this study implies that any claims on the determinants of firm growth depend on how firm growth is measured. It shows that affiliate investment can be adopted as a good channel to boost some dimensions of firm growth but not all. Empirically, this study provides new evidence that private-controlled firms are more efficient than government-controlled firms in terms of affiliate investment, and corporate investment decisions by private investors are more value-enhancing than that of government shareholders. While affiliate investment can be utilised as a channel for corporate diversification into new business lines as already mentioned, this strategy should be adopted by private firms only for firm growth. Hence, this finding is also beneficial to the literature on corporate diversification. Besides, the finding for the effect of foreign ownership suggests that multinational corporations may encounter contradicting scenarios of financial growth rates in a host country. As mentioned earlier, foreign ownership is found to be positively associated with sales growth, but it has a negative impact on asset growth in the context of an Asian emerging economy like Vietnam.

This paper has some limitations. First, under the equity method in accounting, affiliate investment appears in the balance sheet as a part of the firm's total assets. Thus, there is a limitation in finding an alternative proxy of affiliate investment that covers all forms of long-term financial investment into subsidiaries, joint ventures and affiliates. Second, due to the focus of research, this study has not discussed the links between affiliate investment and corporate risk-taking behaviors. Further research examine the relationships among affiliate investment, corporate risk management and firm growth.

\section{References}

Adams, M., Andersson, L. F., Hardwick, P., \& Lindmark, M. (2014). Firm size and growth in Sweden's life insurance market between 1855 and 1947: A test of Gibrat's law. Business History, 56(6), 956-974.

Aktas, N., Croci, E., \& Petmezas, D. (2015). Is working capital management value-enhancing? Evidence from firm performance and investments. Journal of Corporate Finance, 30, 98-113.

Alperovych, Y., Hübner, G., \& Lobet, F. (2015). How does governmental versus private venture capital backing affect a firm's efficiency? Evidence from Belgium. Journal of Business Venturing, 30(4), 508-525.

Arellano, M., \& Bond, S. (1991). Some Tests of Specification for Panel Data: Monte Carlo Evidence and an Application to Employment Equations. The Review of Economic Studies, 58(2), 277-297.

Arellano, M., \& Bover, O. (1995). Another look at the instrumental variable estimation of error-components models. Journal of Econometrics, 68(1), 29-51.

Audretsch, D. B., Klomp, L., Santarelli, E., \& Thurik, A. R. (2004). Gibrat's Law: Are the Services Different? Review of Industrial Organization, 24(3), 301-324.

Blandina, O., \& Adelino, F. (2005). The Dynamics of the Growth of Firms: Evidence from the Services Sector. In: GEMF - Faculdade de Economia, Universidade de Coimbra.

Blundell, R., \& Bond, S. (1998). Initial conditions and moment restrictions in dynamic panel data models. Journal of Econometrics, 87(1), $115-143$.

Calvo, J. L. (2006). Testing Gibrat's Law for Small, Young and Innovating Firms, 117.

Cameron, A. C., \& Trivedi, P. K. (2010). Microeconometrics using Stata (Rev. ed.): College Station, Tex. : Stata Press.

Capasso, M., Treibich, T., \& Verspagen, B. (2015). The medium-term effect of R\&D on firm growth. Small Business Economics, 45(1), 3962.

Chadha, S., \& Sharma, A. K. (2015). Capital Structure and Firm Performance: Empirical Evidence from India. Vision, $19(4), 295-302$.

Chen, T.-J., \& Ku, Y.-H. (2000). The effect of foreign direct investment on firm growth: the case of Taiwan's manufacturers. Japan and the World Economy, 12(2), 153-172.

Chih-Ping, Y. (2016). Size and growth of mobile phone firms in Mainland China, Hong Kong, and Taiwan. Chinese Economy, 49(4), 277286.

Cleary, S. (1999). The relationship between firm investment and financial status. The Journal of Finance, 54(2), 673-692.

Coad, A. (2009). The growth of firms: A survey of theories and empirical evidence: Edward Elgar Publishing.

Coad, A., \& Rao, R. (2010). Firm growth and R\&D expenditure. Economics of Innovation and New Technology, 19(2), $127-145$.

Coad, A., Segarra, A., \& Teruel, M. (2016). Innovation and firm growth: Does firm age play a role? Research policy, 45(2), 387-400.

Copeland, T. E., Weston, J. F., \& Shastri, K. (2005). Financial theory and corporate policy: Boston, MA : Addison-Wesley, 4th ed.

Cumming, D. J., Grilli, L., \& Murtinu, S. (2017). Governmental and independent venture capital investments in Europe: A firm-level performance analysis. Journal of Corporate Finance, 42, 439-459.

Daily, C. M., \& Thompson, S. S. (1994). Ownership structure, strategic posture, and firm growth: An empirical examination. Family Business Review, 7(3), 237-249.

Daunfeldt, S.-O., \& Elert, N. (2013). When is Gibrat's law a law? Small Business Economics, 41(1), 133-147.

Dimelis, S. P. (2005). Spillovers from foreign direct investment and firm growth: Technological, financial and market structure effects. International Journal of the Economics of Business, 12(1), 85-104.

Djankov, S., \& Murrell, P. (2002). Enterprise restructuring in transition: A quantitative survey. Journal of economic literature, 40(3), 739792.

Douma, S., George, R., \& Kabir, R. (2006). Foreign and Domestic Ownership, Business Groups, and Firm Performance: Evidence from a Large Emerging Market. Strategic Management Journal, 27(7), 637-657. doi:10.1002/smj.535 
Dushnitsky, G., \& Lenox, M. J. (2006). When does corporate venture capital investment create firm value? Journal of Business Venturing, 21(6), 753-772.

Engel, D., \& Keilbach, M. (2007). Firm-level implications of early stage venture capital investment-An empirical investigation. Journal of Empirical Finance, 14(2), 150-167.

Federico, J., \& Capelleras, J.-L. (2015). The heterogeneous dynamics between growth and profits: the case of young firms. Small Business Economics, 44(2), 231-253. doi:10.1007/s11187-014-9598-9

Gainsborough, M. (2009). Privatisation as State Advance: Private Indirect Government in Vietnam. New Political Economy, 14(2), $257-274$. doi:10.1080/13563460902826013

Gedajlovic, E., \& Shapiro, D. M. (2002). Ownership Structure and Firm Profitability in Japan. The Academy of Management Journal, 45(3), 565-575.

Geroski, P. A., \& Gugler, K. P. (2001). Corporate Growth Convergence in Europe. In: C.E.P.R. Discussion Papers.

Geroski, P. A., Lazarova, S., Urga, G., \& Walters, C. F. (2003). Are Differences in Firm Size Transitory or Permanent?, 47.

Gibrat, R. (1931). Les inégalités économiques: Recueil Sirey.

Goddard, J., Molyneux, P., \& Wilson, J. O. (2004). Dynamics of growth and profitability in banking. Journal of Money, Credit and Banking, 1069-1090.

GSO. (2016). The Movement and Reality of Socio-Economic Situation in Vietnam over the 5-year Period from 2011-2015 In.

Hidenobu, O., \& Lai Thi Phuong, N. (2012). Capital Structure and Investment Behavior of Listed Companies in Vietnam: An Estimation of the Influence of Government Ownership. International Journal of Business and Information, 7(2), 137.

IFC. (2010). Corporate Governance Manual (2nd ed.). Hanoi.

Jang, S., \& Park, K. (2011). Inter-relationship between firm growth and profitability. International Journal of Hospitality Management, 30 , 1027-1035. doi:10.1016/j.ijhm.2011.03.009

Jensen, M. C., \& Meckling, W. H. (1976). Theory of the firm: managerial behavior, agency costs and ownership structure. Journal of Financial Economics, 3(4), 305-360.

Kankaanpää, J., Oulasvirta, L., \& Wacker, J. (2014). Steering and Monitoring Model of State-Owned Enterprises. International Journal of Public Administration, 37(7), 409-423. doi:10.1080/01900692.2013.858355

Kim, K.-H., \& Rasheed, A. A. (2014). Board heterogeneity, corporate diversification and firm performance. Journal of Management Research, 14(2), 121.

Konings, J. (1997). Firm growth and ownership in transition countries. Economics Letters, 55(3), 413-418.

Lee, S. (2014). The relationship between growth and profit: evidence from firm-level panel data. Structural Change and Economic Dynamics, $28,1-11$.

Megginson, W. L., Nash, R. C., \& Randenborgh, M. (2012). The financial and operating performance of newly privatized firms: An international empirical analysis. The Journal of Finance, 49(2), 403-452.

Nguyen, T. N. (2013). Determinants of Firm Growth in the Vietnamese Commercial-Service Sector. Journal of Economics and Development, $14(1), 57$.

Nguyen, T. T., \& Van Dijk, M. A. (2012). Corruption, growth, and governance: Private vs. state-owned firms in Vietnam. Journal of banking \& finance, 36(11), 2935-2948.

Penrose, E. T. (1956). Foreign investment and the growth of the firm. The economic journal, 66(262), 220-235.

Pham, C. D., \& Carlin, T. M. (2008). Financial performance of privatized state-owned enterprises (SOEs) in Vietnam. Journal of International Business Research, 7(3), 105.

Phung, D. N., \& Mishra, A. V. (2016). Ownership Structure and Firm Performance: Evidence from Vietnamese Listed Firms. Australian Economic Papers, 55(1), 63-98. doi:http://onlinelibrary.wiley.com/journal/10.1111/\%28ISSN\%291467-8454/issues

Rasiah, D., Tong, D. Y. K., \& Kim, P. K. (2014). Profitability and Firm Size-Growth Relationship in Construction Companies in Malaysia From 2003 to 2010. Review of Pacific Basin Financial Markets \& Policies, 17(3), 1-19. doi:10.1142/S0219091514500143

Roberta, D., Ivan, P., \& Emiliano, S. (2014). Size, Age and the Growth of Firms: New Evidence from Quantile Regressions. In: Fondazione Eni Enrico Mattei.

Roodman, D. (2009). How to do xtabond2: An introduction to difference and system GMM in Stata. Stata Journal, 9(1), 86-136.

Scott, W. R. (2015). Financial accounting theory: Don Mills, Ontario : Pearson Canada, [2015], 7th edition.

Sun, Q., \& Feng, F. (2004). Do government-linked companies underperform? Journal of banking \& finance, 28(10), $2461-2492$.

Tang, A. (2015). Does Gibrat's law hold for Swedish energy firms? Empirical Economics, 49(2), 659-674. doi:10.1007/s00181-014-0883-x

Truong, D. L., Lanjouw, G., \& Lensink, R. (2006). The impact of privatization on firm performance in a transition economy - The case of Vietnam. ECONOMICS OF TRANSITION, 14(2), 349-389.

Weill, P. (1992). The relationship between investment in information technology and firm performance: A study of the valve manufacturing sector. Information systems research, 3(4), 307-333.

Xiu-fang, L., Xiao-jiao, B., \& Chao, A. (2013). The Growth Model of Life Insurance Companies: Based on the Empirical Test of the Gibrat Law. Insurance Studies, 3, 010.

Yang, W., \& Meyer, K. E. (2018). How does ownership influence business growth? A competitive dynamics perspective. International Business Review.

Zhou, H., \& de Wit, G. (2009). Determinants and dimensions of firm growth. SCALES EIM Research Reports (H200903). 
(C) 2020 by the authors; licensee Growing Science, Canada. This is an open access article distributed under the terms and conditions of the Creative Commons Attribution (CC-BY) license (http://creativecommons.org/licenses/by/4.0/). 